\title{
キオスクを火源とする模擬線路階の火災実験 \\ A FULL-SCALE FIRE TEST OF A KIOSK IN A STEEL STRUCTURE SIMULATING THE TRACK STOREY
}

石 橋 輝 樹*, 蓮田 常 雄**, 藤井 光治郎***

Teruki ISHIBASHI, Tuneo HASUDA and Kojiro FUJII

The track storey is located at the lowest part of the over-track building, and therein at least two independent open spaces are furnished, so the fire behaviour is totally different from that in the general buildings. In order to study the fire engineering design method of the over-track building, we conducted a series of full-scale fire tests of a kiosk ( a principal origin of fire on the track storey)in a steel structure simulating the track storey, and grasped the fundamental fire behavior on the track storey.

Keywords : fire, fire load, heat-release, fire engineering design, station 火災、火災荷重、発熱速度、耐火設計、駅

\section{1.はじめに}

近年、鉄道の線路上空を利用して、駅および旅客の利 便に関連する機能が合体した複合用途の線路上空建築物 の建設が進められている（図-1）。

この線路上空建築物は、駅部分として一般に第 1 首 （最下層）に線路階（線路、ホーム等が設置され、列車 の発着や旅客の乗降が行われる階）を有するのを特徴と する。また線路階の直上には一般建築諸室の他、駅部分 として改札、出札、駅務室、旅行センター、およびコン コース等が位置する。この階より上部の階は、店舗や事 務室等で構成され一般建築物之の美は無い。これら線路 上空建築物の構造種別は、施工性等の理由により鉄骨造 が大半を占める。線路階はその空間構成上、少なくとも 線路出入口の 2 方向が開放され、また天井の高さ等空間 形状も列車が運行するため建築限界" の制約を受ける。 さらに、可燃物の種類や量もキオスク（駅の独立した小 規模物販店舖）や列車（不燃化されていない場合）に限
定されているなど火災性状を考える上で、一般の建築物 とは異なる特徴を有する。

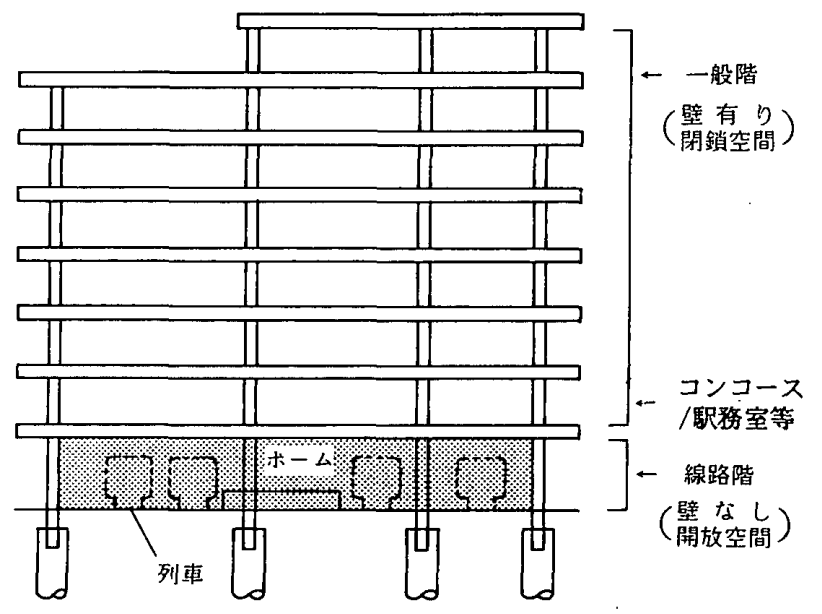

図 -1 線路上空建築物

* 瞅鉄道総合技術研究所 建筑研究空長 - 工修 Chief, Architecture Lab., Railway Technical Research Institute,

* 时鉄道緿合技術研究所 建築研究室主任研究買

*** 盼鉄道総合技術研究所 建築研究室研究係長· 工俢
M. Eng.

Senior Researcher, Architecture Lab., Railway Technical Research Institute

Researcher, Architecture Lab., Railway Technical Research Institute, M. Eng. 
近年、実火災性状に基つく部材温度予測、応力。変形 解析により建築物の安全性を確認する新しい耐火設計法

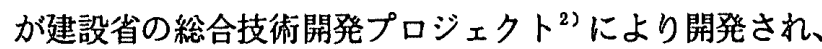
換気支配型の区画火災を对象とする一般建築物について 設計法が示されている。しかし、上記の線路上空鉄道駅 の線路階については、未だ正確な可燃物量や火災性状が 明らかでない。

このような背景のもとに、本論文では、線路上空鉄道 駅の合理的な耐火設計法確立のため、臤の正確な可燃物 量の調查に基づき、主な可燃物であるキオスクを火源と する線路階を模擬した火災実験を行い火災性状を把握し たので報告する。

\section{2. 铁道駅の可㜣物量}

2.1 主要用途空間における可燃物量

著者等が行った首都圈の線路上空鉄道駅および地平駅 9 駅（垂車客 2.5 万人以上で鉄骨造の駅から選択）を 対象とした可然物調查 ${ }^{324)}$ によると、駅の主な用途空間 についての火災荷重（単位床面積に対する木材重量に換 算した等価可然物量）は表-1に示すとおりである。

表一 1 駅主要用途空間における火災荷重

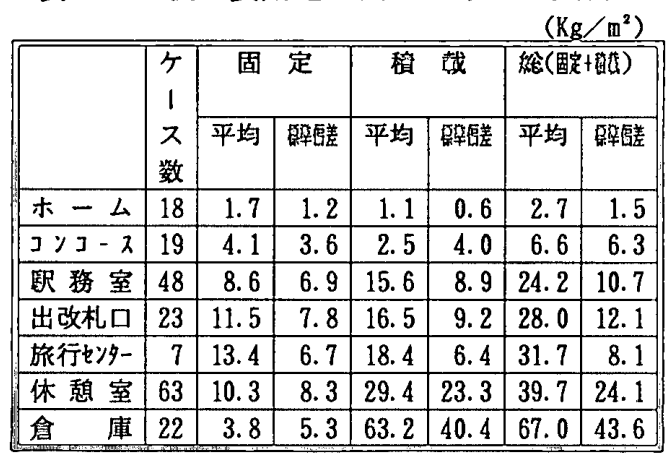

また、図-2に各用途空間の面積と可燃物量の関係を示 す。ホームおよびコンコースの主な可燃物はキオスクで ありホームおよびコンコース全面積を対象とした火災荷 重の值は小さく、可燃物の総量は面䅡に単純に比例せず キオスクの設置個效に大きく影算される。

駅務室、出改札室の可燃物の総量は面皘に比例し、総 火災荷重はほほ一定の値をとる。総火災荷重に占める積 载火災荷重の割合は58～68\%となっている。駅の休蒩室 および倉庫の火災荷重は、面積が一般に小さく、また積 载物の種類や量も変動するのでばらつきが大きい。

表-2に一般建築物諸室の積载火災荷重を示す ${ }^{225) 。 こ ~}$ れと駅用途空間を比較すると駅弱室、出改札室、および 旅行セン夕ーは一般建築物の事務室とよい対応を示す。

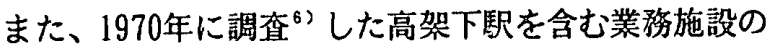

火災荷重と比皎すると（図-3）、固定、積載火災荷重共 今回の調查結里の方が、総火災荷重で約 $30 \sim 70 \%$ に減少 しており、OA化やスチール家具導入等による駅の不燃 化が進んでいることを示している。
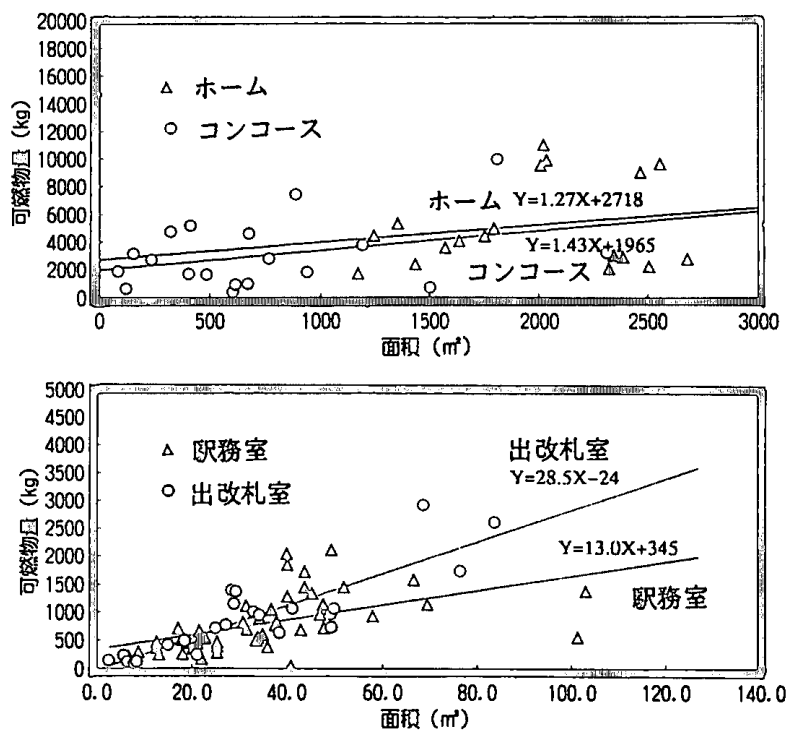

図-2 可燃物量一床面積関係

表 -2 一般建築物の積载火災荷重

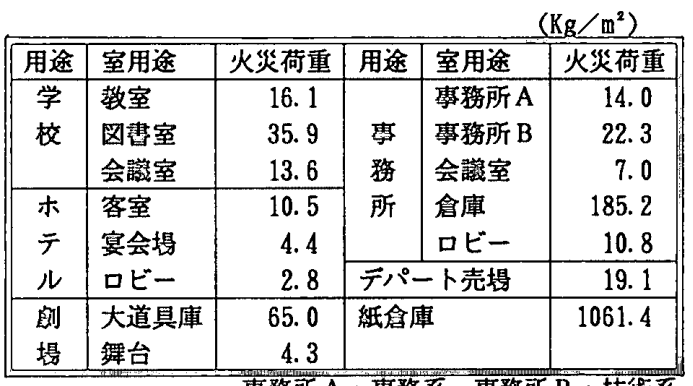

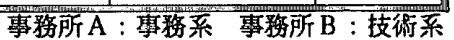

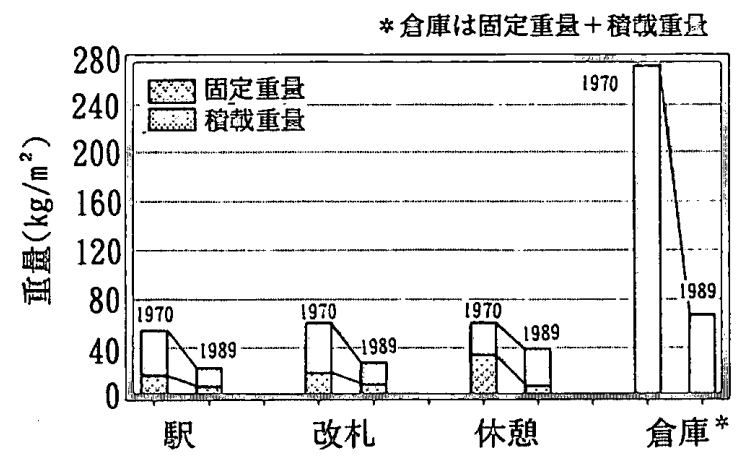

図 - 3 駅の火災荷重の推移

\section{2 キオスクの可燃物量}

今回の駅可燃物調査 32 4) によるキオスクの積载火災荷 重の平均值 (6体) は $87.3 \mathrm{~kg} / \mathrm{m}^{2}$ 、最大値は $98.4 \mathrm{~kg} / \mathrm{m}^{2}$ で 
ある。さらに比較のために行った取扱㣍目リストによる 都心 $S$ 駅のキオスク( 店舖面積 $8.2 \mathrm{~m}^{2}$ 、単位面積当たり 取扱量は最大クラス）の調查結果では、火災荷重は104. $8 \mathrm{~kg} / \mathrm{m}^{2}$ であり、駅調查の結果とよい一致をみている。

キオスクの固定火災荷重は、上記調查によると平均值 （6体）は $60.2 \mathrm{~kg} / \mathrm{m}^{2}$ 、最大值は $102.4 \mathrm{~kg} / \mathrm{m}^{2}$ である。 キオスクの店舖面積は、 $6 \sim 8 \mathrm{~m}^{2}$ の小規模なものが多く $15 \mathrm{~m}^{2}$ 程度以下のものが大半を占める。上記の駅調查によ る40店舖の面積分布を図-4に示す。

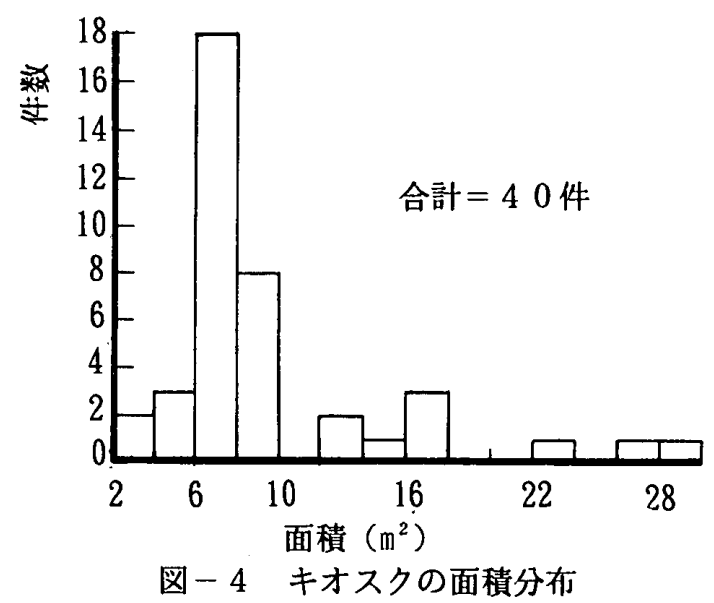

\section{3. キオスク火災実験}

\section{1 実験概要}

建築物の燃焼性状を把握するための実大火災実験は、 昭和 8 年の東京帝国大学における木造家屋の火災実験を はじめとし種々実施され、昭和 50 年代にも木造枠組壁 工法や在来工法 ${ }^{7}$ 、鉄銅系プレ八ブ住宅 ${ }^{8)}$ といった住宅 関係実大火災実験が行われている。しかし、開放空間や 大空間を対象とする木質系可燃物を火源とする実大火災 実験は蔵前国技館の例 ${ }^{9}$ 等少数にとどまり、キオスクを 火源にした実験は行われていない。

そこで、キオスクを火源とする線路階火災の基本性状 とその線路階架構への影響を把握するため、線路階を模 擬した実大の 1 首 1 スパン $\times 1$ スパンの鉄骨架構の中で

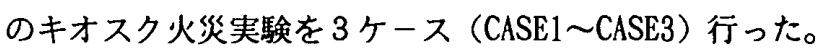
（1）供試体

供試体はいずれも首都圈で使用されていたキオスクで CASE1 CASE3の 3 体の形状、寸法を図-5に示す。積載可 燃物はキオスクの実状に合わせ、新聞・雑誌・文庫本・ 雑貨を配置した。積載火災荷重は、前述の可㜣物調查に もとづき $100 \mathrm{~kg} / \mathrm{m}^{2}$ とした。固定火災荷重は、3体平均す ると $106.3 \mathrm{~kg} / \mathrm{m}^{2}$ 、最大で $143 \mathrm{~kg} / \mathrm{m}^{2}$ である。駅調查結果よ り大きな値なのは、軸組が木造で雑誌棚等木部体積が大 きいためである。キオスク天井はカラ一鉄板莫で、背面 に鉄製シャッターが格納されている。
線路階を模擬した実大の鉄骨架構は、1 層 1 スパン× 1 スパン $(12 \mathrm{~m} . \times 15 \mathrm{~m}) て ゙$ 屋根面はALC 版とした。ALC 版 は、梁の上に載せるだけで梁の変形を拘束しないように 配虑した。
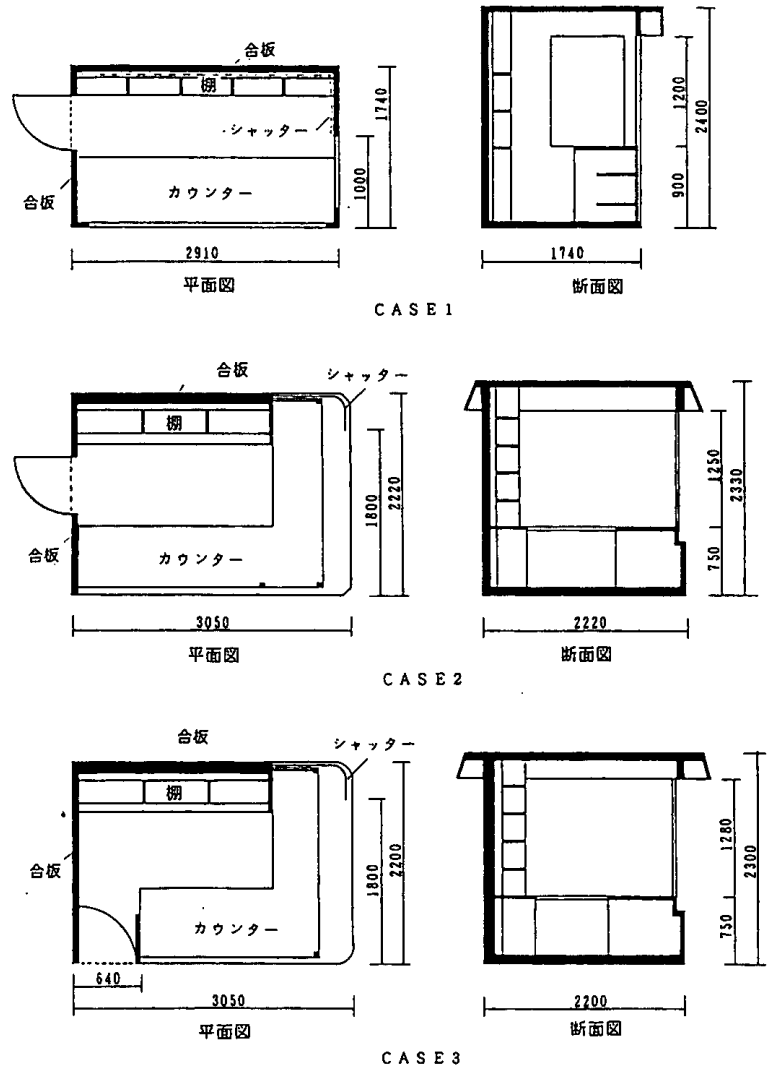

図-5 キオクス供試体の形状、寸法

図-6に架構の概略を示す。ホームを模擬するため架構内 部に架台を設け、その上にキオスクを設置した。架台か ら大梁下端までの距離は $4.2 \mathrm{~m} て ゙ 、$ 架台から $0.7 \mathrm{~m}$ 上方のキ オスクカウンター高さに相当する位置を高さの基㔼（以 下基準高さ）とし、またキオスク開口近傍の鉄骨柱に対 する火災の影響を調へるため模擬柱 3 本を付加した。

実験は、キオスク設置位置、壁の有無をパラメーーター とし 3 ケース行った（表-3）。

（2）測定方法

燃焼速度は、燃焼による重量減少を測定することによ り算出することとし、実験中架台重量をロードセル 3 台 で計量した。輻射は輻射計をキヨスク前面と侧面からそ れぞれ3m 離し基準高さから0.5m上方に設置し測定した。

雾囲気温度分布は、キオスク供試体周囲にワイヤで1m ピッチの立体座標を組み、熱電対 $(C A \phi 1.6)$ により計測 した（計測点数 113点）。鉄骨温度は、鉄骨部材に熱電 対（シース 熱電対 $\phi 1.6$ )を埋め込み測定した（柱59点、梁 60点）。本実験ではさらに火災の影響による鉄骨架構の 変形性状を測定するため、X 2 通りの 2 階床面上部に断 
熱材で防護した基準梁を設け、大梁の軸方向伸び、鉊直 および横たわみを基準梁からの相対変形として測定した （図-7）。計測時間間隔は15秒とした。火炎形状はビテ オ、写真撮影により行った。

実験の全体状況を写真-1に示す。
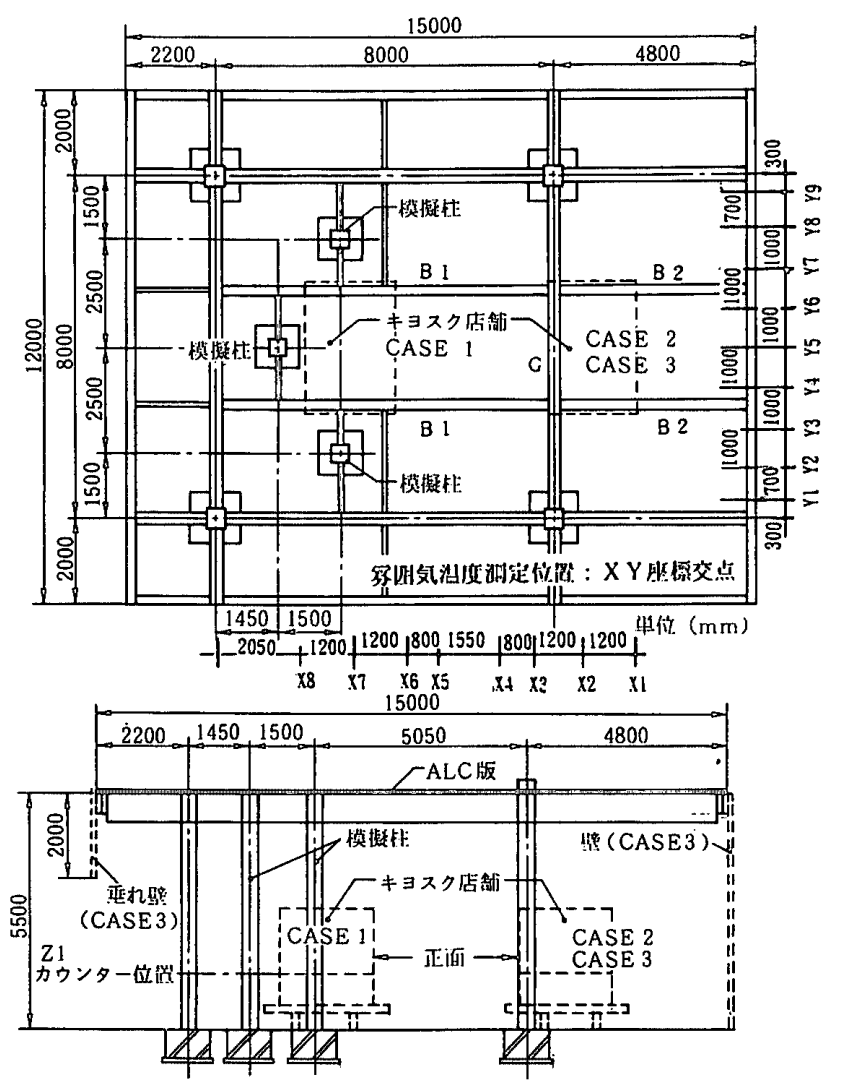

部材唀小

G $\mathrm{H}-700 \times 300 \times 13 \times 24 \mathrm{~B} 1 \mathrm{~s}$ 梁 $\mathrm{H}-500 \times 200 \times 10 \times 16$ 世 $=-400 \times 400 \times 19$ B 2 梁 $\mathrm{H}-294 \times 200 \times 8 \times 12$

図 -6 線路階架構概略

表 -3 実験条件とキオスク諸元

\begin{tabular}{|c|c|c|c|c|}
\hline & 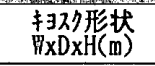 & $\begin{array}{c}\text { 全可焱物是 } \\
(\mathrm{Kg})\end{array}$ & 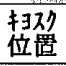 & $\begin{array}{l}\text { 竑の } \\
\text { 無 }\end{array}$ \\
\hline CASE1 & $2.9 \times 1.7 \times 2.4$ & 900 & 中央 & なし \\
\hline CASE2 & $3.1 \times 2.2 \times 2.3$ & 1340 & 端部 & なし \\
\hline CASE3 & $3.1 \times 2.2 \times 2.3$ & 1630 & 端部 & あり \\
\hline
\end{tabular}

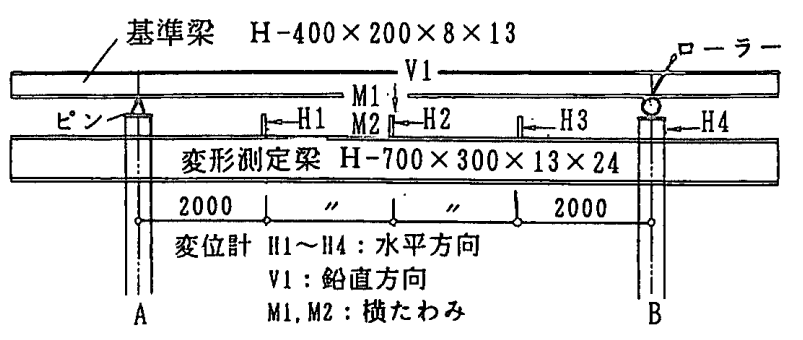

図 - 7 鉄骨梁の変形測定概略

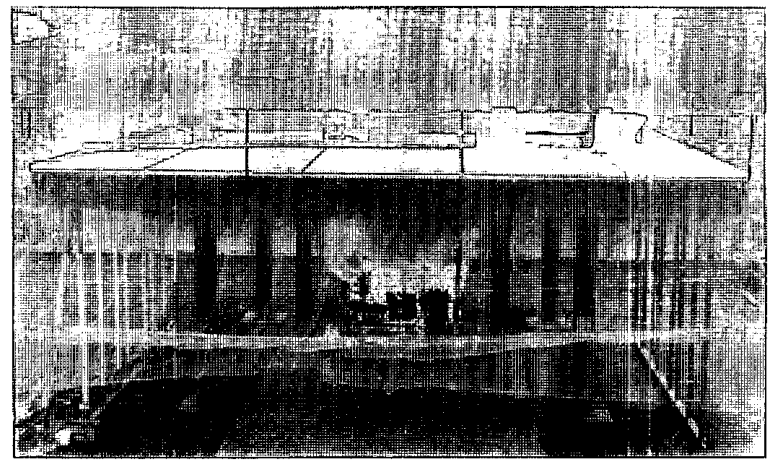

写真-1 実験の全体状況

\section{（3）実験経過}

着火方法は、キオスク床位置中央に液体燃料（ $\mathrm{N}-$ プタン） 0.5 〕入りの火皿を置き着火源とした。実験は着 火後キオスク内が火炎に包まれるフラッシュオーバー、 火盛り期を経て冷却期に移行し火勢が衰えるまで行った。 火炎は開口から噴出したが、火盛り期以降側壁部分から の噴出もみられた。

\section{2 実験結果と考察}

（1）可燃物燃焼重量－時間関係

可燃物燃焼重量 - 時間関係を図-8、実験結果一覧を表 -4に示す。可燃物燃焼重量－時間関係が急変する時間を フラッシュオーバー時刻とし見掛けの時間原点とした。 各時間原点の着火後の経過時間は、CASE1〜3がそれぞれ 3分、4分、22分（CASE3は自然鎮火したため、17.5分後に 再着火した。)である。

CASE1 〜CASE3 の各ケースともフラッシュオーバー以 降8 15分継続する火盛り期では燃焼速度一定であり、そ

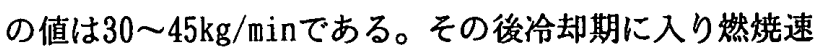
度は急減し火盛り期の $1 / 2 \sim 1 / 3$ 程度でほぼ一定値をとる。 この傾向は、キオスクの基本燃焼性状を把挃するために 行われた自由空間での燃焼試験 ${ }^{10)}$ でも明らかになって おり、燃焼重量一時間関係は 2 直線で近似できると考え られる。また、火盛り期終了時には全可燃物量の約 $1 / 3$ 、 フラッシュオーバー後約 30 分を経過すると全可燃物量の 約 $1 / 2$ が燃焼し火勢が衰えた。

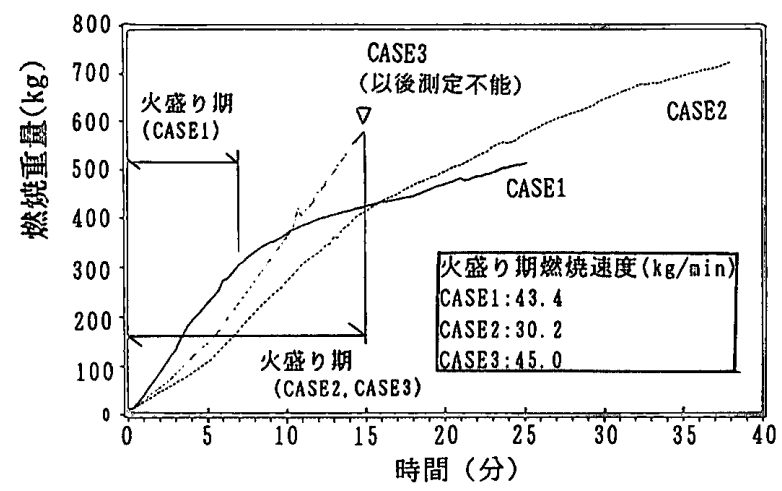

図-8 可燃物燃焼重量一時間関係 


\section{表 - 4 キオスク燃焼速度等一覧}

\begin{tabular}{|c|c|c|c|c|}
\hline \multicolumn{2}{|l|}{ 試験体名 } & CASE1 & CASE2 & CASE3 \\
\hline \multicolumn{2}{|c|}{ 店舗面積 $\left(\mathrm{m}^{2}\right)$} & 5.06 & 6.77 & 6.71 \\
\hline \multirow{4}{*}{$\begin{array}{c}\text { 可燃物量 } \\
(\mathrm{Kg}) \\
\text { (火災荷重) } \\
\left(\mathrm{Kg} / \mathrm{m}^{2}\right)\end{array}$} & 固 定 & $\begin{array}{l}394 \\
(78)\end{array}$ & $\begin{array}{l}663 \\
(68)\end{array}$ & $\begin{array}{c}959 \\
(143)\end{array}$ \\
\hline & 積 载 & $\frac{1109}{506}$ & 677 & 671 \\
\hline & & $(100)$ & $(100)$ & $(100)$ \\
\hline & 合 計 & $\begin{array}{c}900 \\
(178)\end{array}$ & $\begin{array}{l}1340 \\
(198)\end{array}$ & $\begin{array}{l}1630 \\
(243)\end{array}$ \\
\hline \multicolumn{2}{|c|}{ 火盛り期 $\tau$ 1時間(min) } & 7.5 & 14 & 15 \\
\hline \multicolumn{2}{|c|}{ 同燃焼速度（Kg/min） } & 43.4 & 30.2 & 45 \\
\hline \multicolumn{2}{|c|}{ 冷却期燃焼速度 $(\mathrm{Kg} / \mathrm{min})$} & 10.2 & 14.1 & $-* 2$ \\
\hline \multicolumn{2}{|c|}{$\begin{array}{c}\tau_{1} \text { 時燃焼重量 }(\mathrm{Kg}) \\
\text { (初期重量との比) }\end{array}$} & $\begin{array}{c}330 \\
(0.37)\end{array}$ & $\begin{array}{c}415 \\
(0.31)\end{array}$ & $\begin{array}{c}680 \\
(0.42)\end{array}$ \\
\hline \multicolumn{2}{|c|}{$\begin{array}{c}\text { 30分後燃焼重量 ( } \mathrm{Kg}) \\
\text { (初期重量との比) }\end{array}$} & $560^{*}$ & 640 & -.2 \\
\hline
\end{tabular}

*125 分時点からの推定值

*2ロードセルのケーブル焼損のためテータ無し

(2) 輻射一時間関係

輻射一時間関係を図-9に示す。CASE1 〜CASE3 の火盛 り期における平均をとった輻射は、キヨスク正面で約 10 . $6 \sim 16 \mathrm{~kW} / \mathrm{m}^{2}$ 、キヨスク側面で約 $5.9 \sim 8.5 \mathrm{~kW} / \mathrm{m}^{2}$ であり各 実験ケースともそれ以降の冷却期では急減する。キヨス ク側面の輻射が小さいのは開口が小さいことによる。

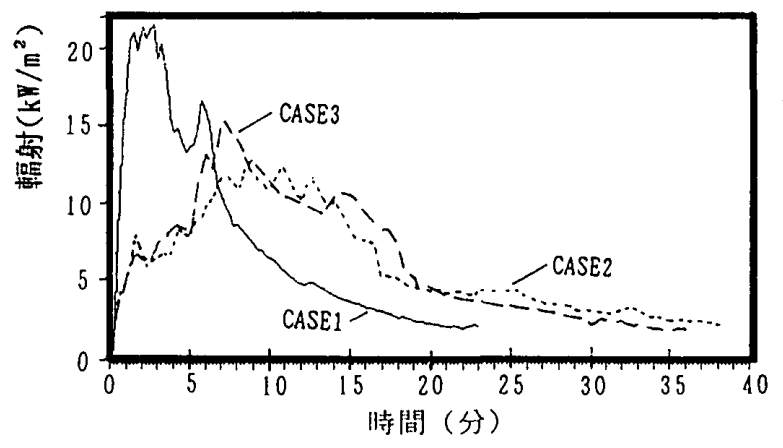

図-9 輻射一時間関係

（3）霂囲気温度

a 、雾囲気温度一時間関係

主要な測定点の霧囲気温度－時間関係を図-10に例示 する。図-10 では 3 测定点とも火盛り期を過ぎ冷却期に 入ると温度が低下するが、火源に近い位置程この傾向が 明瞭である。

\section{b. 雾囲気温度分布}

CASE1 〜CASE3 の火盛り期で平均した雲囲気温度分布 を図-11 に示す。キオスク内部の火災室温度は、823 ${ }^{\circ} \mathrm{C}$ 〜914 ${ }^{\circ} \mathrm{C}$ 達する。火炎がキオスク開口から噴出し、そ の後鈶直に上昇し熱気流が天井面から水平の層となって 拡がっていく様子が明睹である。CASE3は空間の 2 方向に 壁を有するため、基準高さから $4 \mathrm{~m}$ の位置でキオスク背面 上部（壁に近い側）の雲国気温度が他の 2 ケースより高
くなっている。屋根面および背面は鉄板で遮蔽されてい るため、その近傍での雾囲気温度は相対的に低い値にと どまっている。

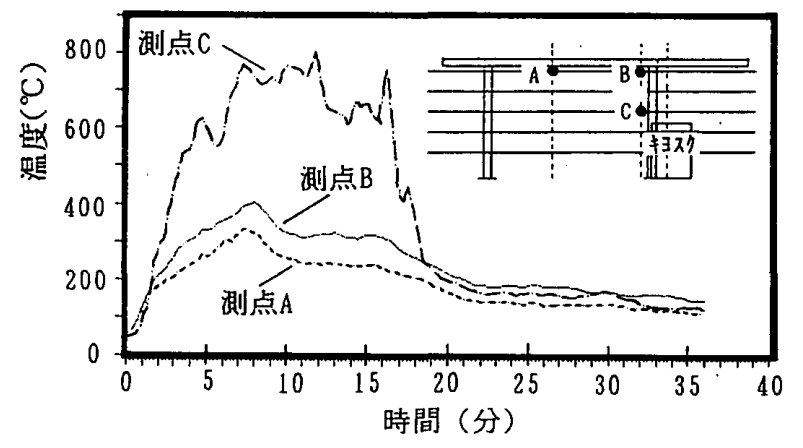

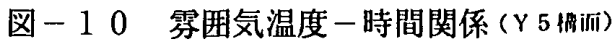
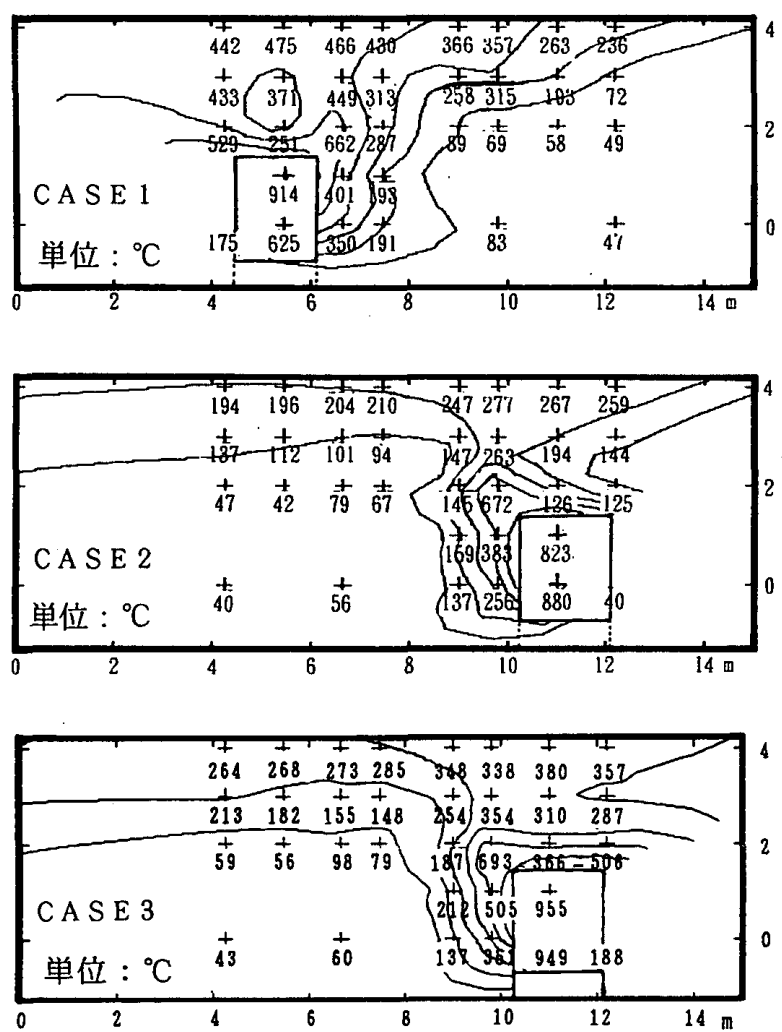

図 - 11 雾囲気温度分布 (Y 5 憎俑)

噴出火炎の軸に沿った温度（火炎軸上温度）の変化に 着目すると、キオスク天井面から上方へ距離に応じて減 衰している。既往の自然換気状態における噴出火炎の火 災実験結果をまとめた火炎の軸上温度が次式で与えられ ている ${ }^{11) 。}$

$$
\left(\frac{T_{z}-T_{0}}{T_{f}-T_{0}}\right)=1-\left(\frac{0.027 \cdot \ell \cdot \mathbb{P}}{R}\right)
$$




$$
\begin{aligned}
& \text { ここに } T_{z} \text { ：火炎軸上温度 }(K) \\
& \mathrm{T}_{1} \text { ：噴出火炎始端での温度 }(\mathrm{K}) \\
& T_{0} \text { 。: 周囲雾囲気温度 }(K) \\
& \ell ： \text { 火炎軸上に沿った火炎始端からの距離 } \\
& \text { 田：開口㽬の和 }(m) \\
& \mathrm{R} \text { ：燃焼速度 }(\mathrm{kg} / \mathrm{s})
\end{aligned}
$$

図-12に( $\left.\frac{T_{z}-T_{0}}{T_{f}-T_{0}}\right)$ と $\left(\frac{\ell \cdot W}{R}\right)$ との関係に整理した CASE1 〜CASE3 の実験值と（1）式との比較を示す。天井 面近傍では煙層の影㗽で差はあるものの傾向は 一致している。

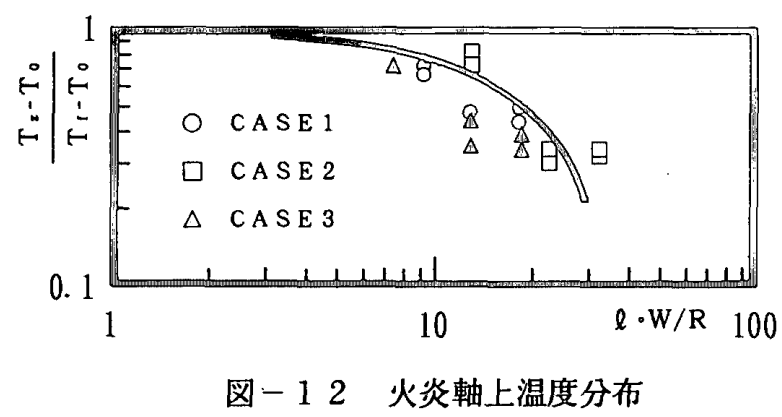

天井面に近接する領域は、噴出火炎からの熱流が天井 面に沿って移動するため比較的遠方まで高温になるが火 源からの水平距離により温度は減衰する。Alpert ${ }^{12)}$ は 、かなり大規模な（発熱速度0.67〜98MW）床面上火源に 対し、周囲が開放された空間における锤々の高さ $(4.6 \mathrm{~m} \sim$ $15.5 \mathrm{~m})$ の天井面に形成される熱気流の性状を調へ天井下 の気流最高温度の予測式を得ている。

$$
\begin{aligned}
\mathrm{T}_{\max }-\mathrm{T}_{0}= & 5.38\left(\frac{\mathrm{Q}_{\mathrm{c}}}{\mathrm{r}}\right)^{2 / 3} / \mathrm{H} \\
& (r>0.18 \mathrm{H}) \\
= & 16.9 \mathrm{Q}_{\mathrm{C}}^{2 / 3} / \mathrm{H}^{5 / 3} \cdots \\
& (r \leqq 0.18 \mathrm{H})
\end{aligned}
$$

ここに $T_{\max }$ : 天井下気流最高温度 $(\mathrm{K})$

$\mathrm{T}_{0}$ ：周囲雾囲気温度 $(K)$

$Q_{c} \quad$ : 発熱速度の対流成分 $(\mathrm{kW})$

$\mathrm{r}:$ : 気流軸からの水平距離 $(\mathrm{m})$

$\mathrm{H}$ : 天井高(m)

無次元化量 $\mathrm{T}_{\mathrm{m}}^{*}$ と $\mathrm{r} / \mathrm{H}$ との関係について、(2)、(3) 式と実験結果を図-13 に示す。

$$
T_{m}^{*}=\left(T_{\max }-T_{0}\right)\left(\frac{C_{P 0}^{2} \cdot p_{0}^{2} \cdot g \cdot H^{5}}{T_{0} \cdot Q_{C}^{2}}\right)^{1 / 3} \cdots(4)
$$

\section{ここに $\mathrm{C}_{\mathrm{P}_{0}}$ : 空気の定圧比熱 \\ ○o : 空気の密度 \\ $\mathrm{g}$ ：重力加速度}

Alpertは初期火災における熱気流性状を対象としたが、 本実験では周囲が解放され換気が充分で、天井下面の雾 囲気温度も比較的安定している（図-10）た少盛り期 の平均的な天井下面の熱気流性状を対象としている。

この図からキオスク火災における $\mathrm{r} / \mathrm{H}$ 対する $\mathrm{T}_{\mathrm{m}}^{*}$ の滅衰は、天井面の梁等により生じる煙層の影偣でいく らか緩僈であるが、実用上Alpertの評価と対応している。

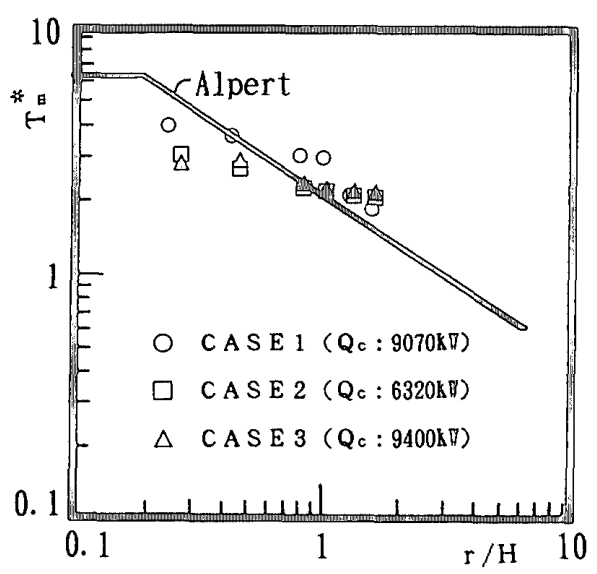

図-13 天井下気流温度分布

（4）火炎形状

a . 火炎形状のビデオ画像による測定

噴出火炎をキオスク正面および側面からビデオ撮影し、 静止画像をCAD を用いて火盛り期 1 分間について1秒ご とに60画面を重好書きすることにより形状解析した（図 -14)。

常に火炎が存在した頒域 (火炎域)は、CAD画面では白 抜きになっている。また、少なくとも1画面に火炎が存 在した領域（間欠火炎域）はCAD 画面で黒い描線の集合 した領域となる。CASE1 〜CASE3 において火炎域高さは 基準高さ（カウンター高さ）から2.0 2.5 m 、左右の 稫はキオスク端部から0.5 0.7mであった。間欠火炎域 高さは3.9 4.6m、間欠火炎域の広がりはキオスク端部 から1.5 1.8mであった。

また、火炎領域を包絡する領域の形状を単純化すると、 キオスク正面および例面ともに、開口下端から開口高さ の約 $1 / 3$ の位置から $45^{\circ}$ 方向に㹡がり開口上端高さから 鉛直方向のびるモデルを考えることができる（図-14 中 の白線）。

（5）鉄骨温度

a. 鉄骨温度一時間関係

火源直上の大梁中央における鉄骨温度一時間関係 $(C A$ 

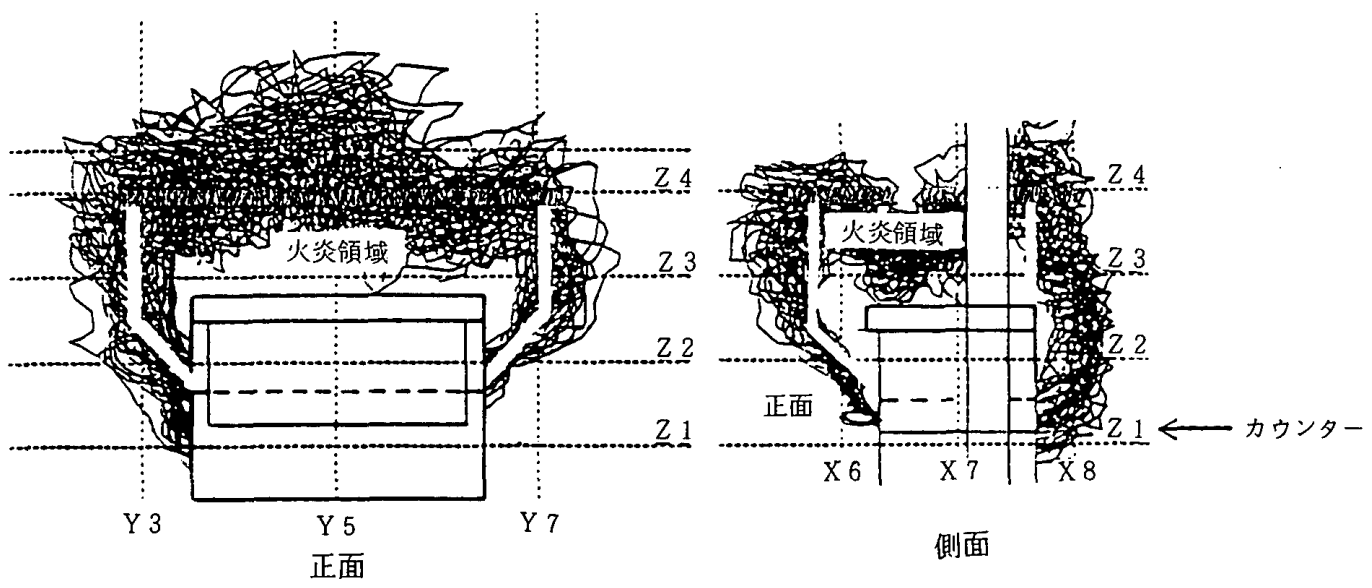

図-14 火炎形状

SE3)を図-15 に示す。鉄骨温度はフラッシュオーバー以 降上昇するが、泠却期に入ると温度の上昇は鈍り温度が 低下する場合も見られる。大梁の下フランジとウェブと の温度はほぼ等しい。キヨスク開口部に近い模擬柱の鉄 骨温度一時間関係 (CASE1)を図-16 に示す。部材各面の 内最も高温になる噴出火炎に相対する面では、温度は火 盛り期で最高に達したあと冷却期に入り急に低下する。 他の面では部材断面内の熱伝導の影響で泠却期に入って も温度は緩やかに上昇を続ける。

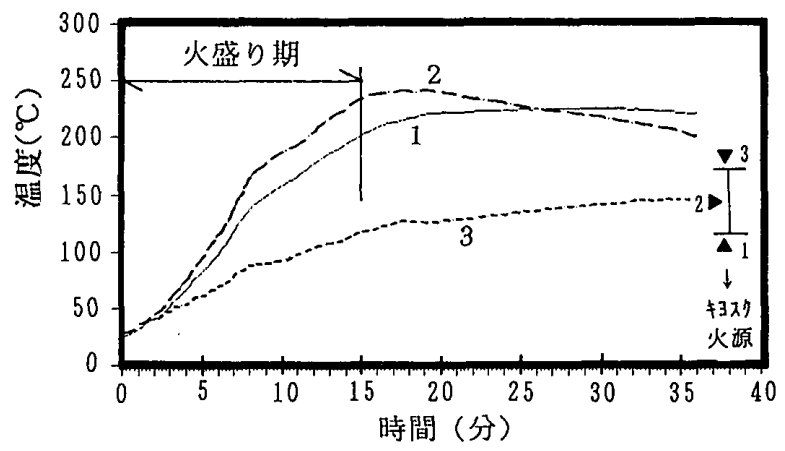

図-15 大梁鉄骨温度－時間関係

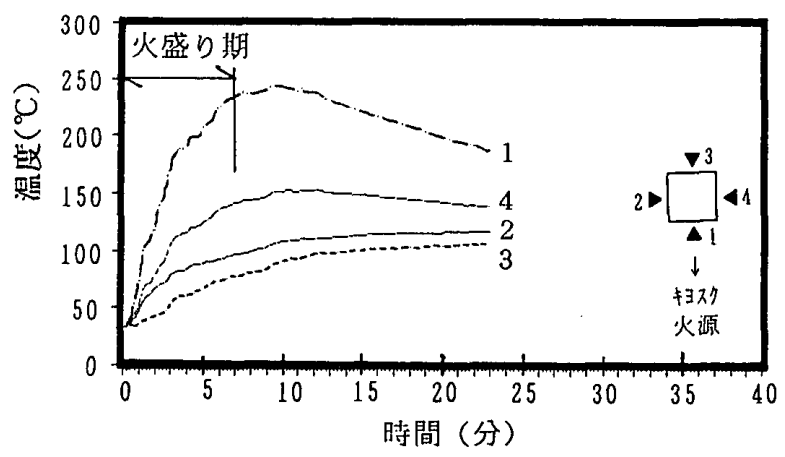

図-16 柱鉄骨温度一時間関係 b. 鉄骨最高温度分布

鉄骨最高温度分布（CASE3）を図-17 に示す。火源直上 梁では部材全長にわたり温度は比較的均等に分布し、下 フランジとウェブの温度がほほ同一で200 250 ${ }^{\circ} \mathrm{C} 、$ 上 フランジとは約 $100{ }^{\circ} \mathrm{C}$ 差があった。柱の温度分布は、 やはり部材全長にわたりほぼ均一で、火源側の面の温度

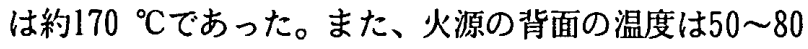

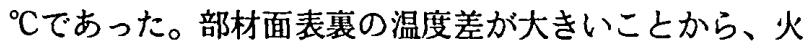
源に近いため輻射の影響が支配的であることが判る。各 実験ケースにおける部材最高温度を表-5に示す。

今回の実験では、CASE1 〜CASE3 とも柱、大梁、小梁、 模擬柱の各部材温度は $350{ }^{\circ} \mathrm{C}$ 以下にとどまった。

c. 架構の変形性状

火源直上の大梁の軸方向伸びー時間関係を図-18 に示 す。軸方向伸びは温度分布に対応し部材各部分でほぼ均 等で、梁全長では $16 \mathrm{~mm}$ に達した。比較のため門形ラーメ ンモデルを対象とし実温度分布( 断面内でも温度差を考

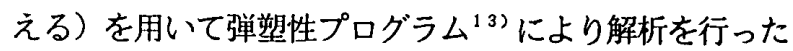
が、変形量は柱脚固定、ピンいずれの場合でも $15.8 \mathrm{~mm}$ なり実験結果と一致した。各ケースにおける变形湘定結 果を表-5に示す。

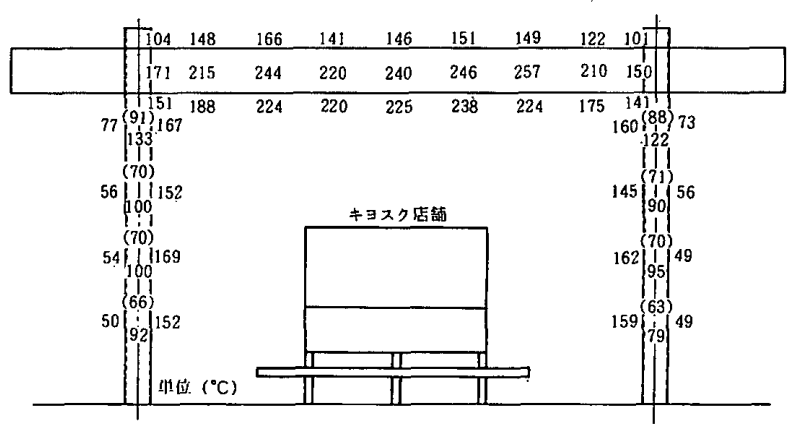

図-17 鉄骨最高温度分布 
表 -5 部材最高温度、架構変形

\begin{tabular}{|c|c|c|c|c|c|c|}
\hline & \multicolumn{4}{|c|}{ 部材最高温度 $\left({ }^{\circ} \mathrm{C}\right)$} & \multicolumn{2}{|c|}{ 架棈笋形 (梁) $(\mathrm{mm})$} \\
\hline & 大梁 & 小梁 & 柱 & 模㩧柱 & 轴伸び & 鉛面変位 \\
\hline CASE1 & 152 & 240 & 89 & 247 & 5.7 & $0.1 * 1$ \\
\hline & 190 & 234 & 148 & 83 & 11. & 0.6 \\
\hline SES3 & 246 & 346 & 169 & 110 & 15.8 & -0.1 \\
\hline
\end{tabular}

*1 上向きを正とする。

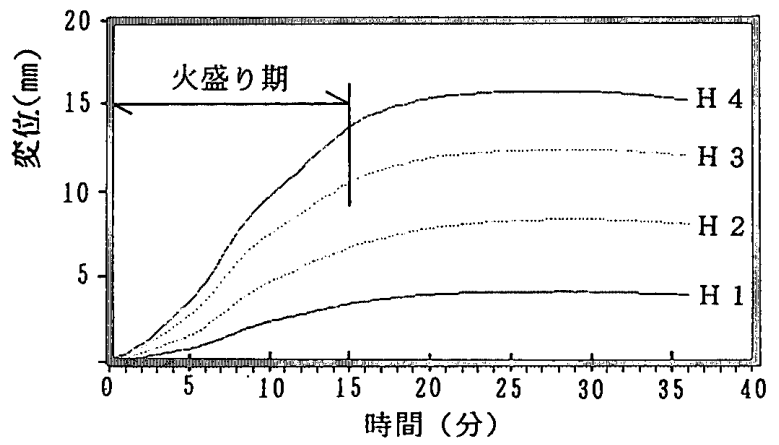

図-18 大梁軸方向伸びー時間関係

\section{4. まとめ}

本論文では線路上空鉄道駅における可燃物の実態を明 らかにし、線路階の主要な可燃物であるキオスクを火源 とする火災実験により、線路階火災の基本的な性状を示 した。

キオスクの燃焼は、開口からの噴出火炎としての性質 の他、一般に正面および侧面の開口が連続し面積も大き いため床上に置かれた矩形火源としての性質も有する。

そして、実験から得られた知見は以下のとおりである。 （1）火災はフラッシュオーバー以降、火盛り期、冷却期 が明瞙な経過をたどり燃焼速度はそれぞれほほ一定で火 盛り期は約 $40 \mathrm{~kg} / \mathrm{min}$, 冷却期はその $1 / 2 \sim 1 / 3$ である。

（2）輻射はキオスク正面 $3 \mathrm{~m}$ 位置で、火盛り期平均約 $16 \mathrm{KW}$ $/ \mathrm{m}^{2}$ に達する。

（3）火炎軸上温度や天井下面気流温度の分布は、実用上 Alpert 等の既往の評価法で説明できる。

（4）常時火炎の存在する火炎域の高さは、基準高さから キオスク開口高さの約2 倍、㽞は開口端から開口高さの $2 / 3$ 倍程度に拡がる。

（5）鉄骨温度は大半が火盛り期終了時に最高温度に達し その後温度は低下する。

\section{謝辞}

本研究は、（財）日本建築防災協会「線路上空利用建 築物耐火設計法技術検討委員会」（委員長 日本大学教 授 岸谷孝一) の研究活動の一環として行われたもので あり、ここに関係各位に謝意を表します。
参考文献

1) 荤翰省合第十四号：普通鉄道梅造規則第二十条 建 筑限界, 1987.3

2）（財）国土開発技術研究センター：建築物の総合防 火設計法 第 4 巻耐火設計法, 1989.4

3) 北澤章他 4 名: 線路上空利用建物における耐火設計 に関する研究 その1 駅の可燃物調查の概要, 日本 建築学会大会学術講演梗概集, A.pp. 1195～1196. 199 1.9

4）藤井他 3 名：線路上空利用建物における酎火設計に 関する研究 その2 駅の可㜣物調㚗結果の分析. 日 本建築学会大会学術㜔演梗摡集, $A$, pp. 1197〜1198, 1991.9

5) 高野均, 斉藤光 : 学校建築の稳载可燃物量に関する 調疽研究，日本建築学会大会学街譐演梗概集, ppl41 $1 \sim 1412,1975.10$

6）铁道銅構造物耐火班：调構造物の耐火に関する研究 （鋀高架駅の耐火について）, JSSC Vol.6 No. 51,pp $1 \sim 53,1970.3$

7 ）日本火災学会：火災便覧 第5 編第 1 章木造建等物 の火災性状, pp431 434.1984.3

8）中村赗一：鉄骨系プレハブ住宅の火災実験，建築研 究資料 No. 40.1983 .1

9 ）勝野上、河崎和夫：葴前国技館の火災実験結果の概 要, 火災 Vol. 35 №. $2,1985.5$

10）石楅楎樹他 4 名：線路上空利用建物における酎火 設計に関する研究 その 3 キヨスク店舗実大火災 実験，日本建筑学会大会学術譐演梗概集、A，pp. 119 $9 \sim 1200.1991 .9$

11 ) Margaret Lam :Fire Safety of External Building Elements, Engineering Journal, American Institute of Steel Construction. Second Quarter .1978

12 ) Alpert, R, L : Calculation of Response Time of Ceiling-Hounted Fire Detectors, Fire Technology . Vol8 pp. 181 195. 1972

13 ) FIRES-FRAMEl :A Computer Program for the Fire Response of Structures of Tall Buildings by $\mathrm{H}$. Koike. H. Uesugi, H.Saito, Chiba University, Faculty of Engineering, Department of Architectural Engineering, MAY 1988

（1994年10月 4 日原稿受理，1995年 2 月 1 日採用決定） 